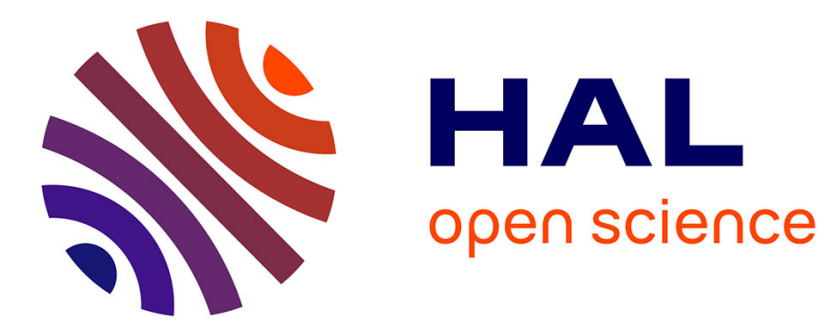

\title{
High temperature mechanical properties of dispersion strengthened copper
}

C. Rigollet, J. Gentzbittel, G. Robert

\section{To cite this version:}

C. Rigollet, J. Gentzbittel, G. Robert. High temperature mechanical properties of dispersion strengthened copper. Journal de Physique IV Proceedings, 1993, 03 (C7), pp.C7-747-C7-750. 10.1051/jp4:19937119 . jpa-00251737

\section{HAL Id: jpa-00251737 https://hal.science/jpa-00251737}

Submitted on 1 Jan 1993

HAL is a multi-disciplinary open access archive for the deposit and dissemination of scientific research documents, whether they are published or not. The documents may come from teaching and research institutions in France or abroad, or from public or private research centers.
L'archive ouverte pluridisciplinaire HAL, est destinée au dépôt et à la diffusion de documents scientifiques de niveau recherche, publiés ou non, émanant des établissements d'enseignement et de recherche français ou étrangers, des laboratoires publics ou privés. 


\title{
High temperature mechanical properties of dispersion strengthened copper
}

\author{
C. RIGOLLET, J.M. GENTZBITTEL and G. ROBERT \\ CEREM/LGM, CENG, BP. 85X, 38041 Grenoble cedex, France
}

\begin{abstract}
Tensile and creep results of oxyde dispersion strenghened copper are presented. The most important features of ODS copper high temperature behaviour are the high strength corresponding to low creep rates, high stress creep rate dependence, a poor ductility and a brittleness wich result in a premature creep fracture at high applied stress
\end{abstract}

Oxyde Dispersion Strenghened (ODS) copper material, due to its excellent thermal conductivity associated with a high temperature strength is a candidate material for structural applications as divertor plasma facing components of thermonuclear fusion reactor. Moreover the material must retain good mechanical properties subsequent to elevated temperature thermal cycles as brazing operations.

This paper presents the tensile and creep properties at elevated temperature of an commercial alumina dispersion strenghened copper : tradename glidcop Al25 in the as received condition and after high temperature thermal cycle.

The commercial dispersion strenghened copper $\mathrm{Al} 25$, containing $0.5 \mathrm{Wt} \%$ alumina, was purchased in $20 \mathrm{~mm}$ diameter rods. These rods were produced by hot extrusion following internal oxidation of copper-aluminium alloy powders. The microstructure consists of fine highly elongated grains: about $5 \mu \mathrm{m}$ length and $0.5 \mu \mathrm{m}$ in diameter) which have a fiber type shape. The fine alumina particles (average size in the range [5-10nm]) identified as tetragonal $j$ or $n^{\prime}$ alumina by indexing ring pattern appear relatively homogeneous dispersed in the grain. In addition a few larger platelets :size $0.1 \mu \mathrm{m}$ looking for $\alpha$ alumina are observed. There is a high dislocation density in the grains or subgrains. in the as received material. The effect of short term annealing $\left(15 \mathrm{mn}\right.$ at $\left.980^{\circ} \mathrm{C}\right)$ on the grain structure is little pronouced. The main effect observed after long term annealing $\left(1000 \mathrm{~h}\right.$ at $\left.700^{\circ} \mathrm{C}\right)$ is the increase of density of large particles analysed as mixed oxyde $9 \mathrm{Al}_{2} \mathrm{O}_{3}-2 \mathrm{~B}_{2} \mathrm{O}_{3}$ located in the grain boudaries.

Tensile tests at different temperatures (up to $980^{\circ} \mathrm{C}$ ) and creep tests at $450^{\circ} \mathrm{C}$ were performed. Without room temperature tensile tests all the tests were carried out under vacuum $\left(2.10^{-5}\right.$ Torr $)$. Specimen for high temperature tests were mechanically polished and then electropolished to produce a defect free surface. This is an important step for creep tests since surface flaws are source of crack initiation which may result in a shorter creep time. 


\section{Results of tensile properties}

The results presented on figures 1 and 2 show the good behaviour at room temperature with an ultimate tensile strength and total elongation reaching $410 \mathrm{MPa}$ and $20 \%$ respectively. The ultimate tensile strength and the yiel strength decrease linearly with temperature and the total elongation present a drop in the temperature range $\left[450^{\circ} \mathrm{C}-750^{\circ} \mathrm{C}\right]$. Moreover at the strain rate concerned $\stackrel{\circ}{\varepsilon}=10^{-4} \mathrm{~s}^{-1}$, the fracture surfaces exhibit :

-a transgranular aspect with dimples a low temperature (figure 3)

- an intergranular aspect above $450^{\circ} \mathrm{C}$ ( figure 4).

The short heating treatment induce a very weak softening but no significant difference of the behaviour.

\section{Creep results}

The creep tests were carried out at $450^{\circ} \mathrm{C}$ in the stress range [100-150MPa]. All the creep curves observed present a very short tertiary stage with a sharp transition from the secondary to the tertiary stage leading in a very short time to failure with a creep elongation being typically less than 3 or $4 \%$. Correlation of creep elongation with time to rupture $\mathrm{tF}$ is reported on figure 5 . It indicates clearly the poor ductility amount at low strain rate. The creep properties ( life time, creep elongation and strain rate ) present a large scatter. The figure 6 reveals the stress dependence of the minimum creep rate, the stress dependence $n$ of the creep rate reaches 30 at $450^{\circ} \mathrm{C}$. Scaning Electron micrograph and optical analysis of the gauge sections and fracture surfaces of the specimens indicated the following aspects:

- a brittle fracture on the great area on the surfaces and characterized by intergranular rupture

- a ductile morphology on a little area with dimples .

\section{Discussion}

The most important features of ODS copper high temperature behaviour are the high creep strength corresponding to low creep rate $\left({ }^{\circ}<1.10^{-6} \mathrm{~h}^{-1}\right)$ compared to dispersion free material. but the poor creep ductility and the brittleness which result in a premature creep fracture at high applied stress. In this temperature range ,about $0.5 \mathrm{Tm}$ (Tm melting temperature) and for for this low deformation rates corresponding to diffusional creep at the boundaries (coble creep) grain boundary sliding contributes at creep deformation. The intergranular britttleness is closely linked to the respective contributions of matrix and grain boundaries to deformation, the damage rate increasing as the grain boudary contribution inceases. The fine alumina dispersion effect on active slip systems, cross slip capacities in the copper matrix and climb control at high temperature is now insufficiently understood. The high dislocation densities effect on creep behaviour and the fine elongated grains may be accentuated the growth and coalesence of cavity during creep and lead to failure of the material.

\section{Conclusion}

ODS copper exhibit a high strength at elevated temperature but a poor ductility Further work: creep tests at different temperatures and TEM observations will be necessary to understand deformation and damage mechanisms • 


\section{Figure 1:}

Temperature effect on ultimate tensile strength. Tests performed with a strain rate $\stackrel{\bullet}{\varepsilon}=10^{-4} \mathrm{~s}^{-1}$

Figure 2:

Temperature effect of total elongation. Tensile tests performed with a strain rate $\stackrel{\bullet}{\varepsilon}=10^{-4} \mathrm{~s}^{-1}$

Figure 3:

SEM micrography of fracture surface. Sample tested at room temperature.
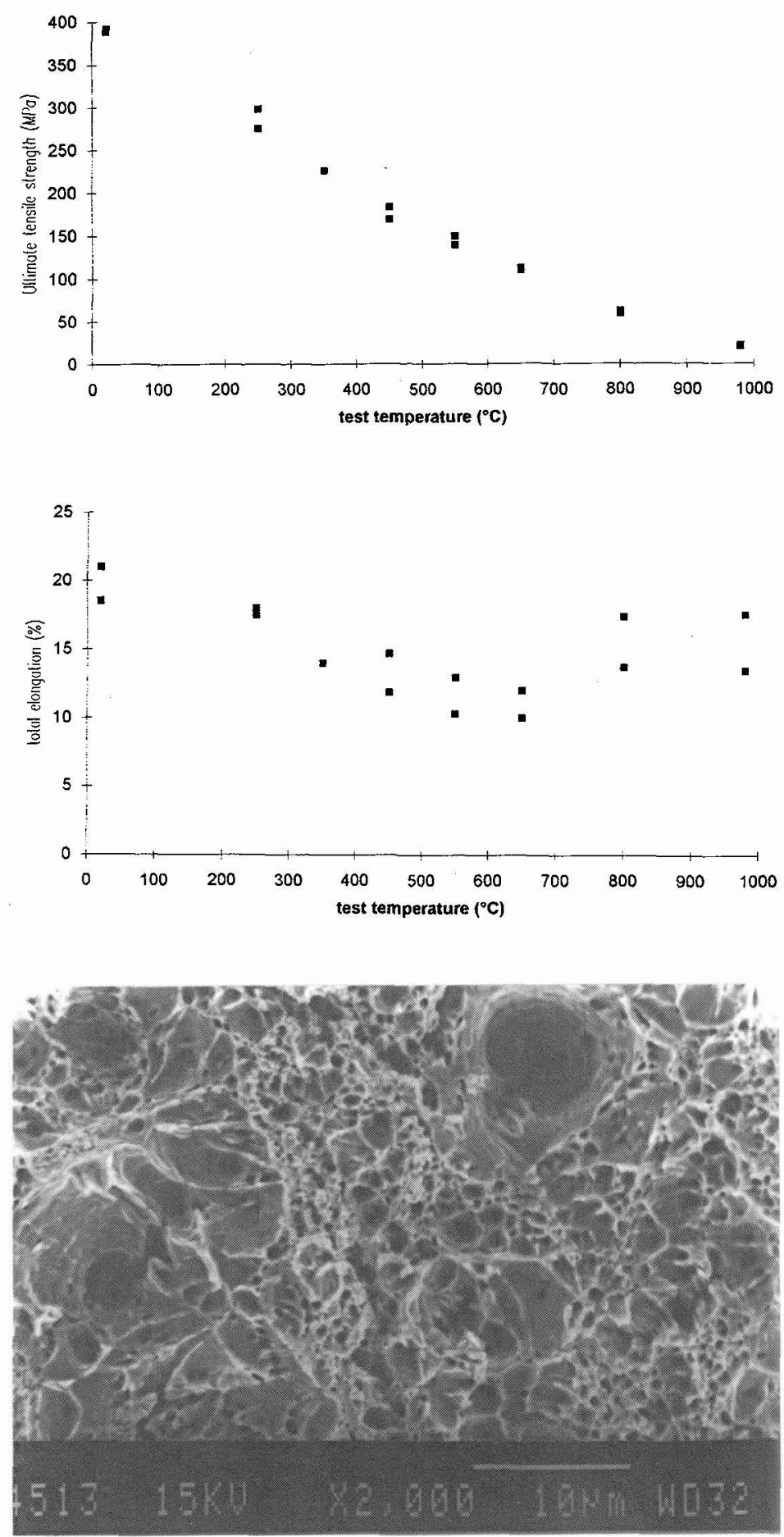
Figure 4:

Fracture surface of sample tested at $650^{\circ} \mathrm{C}$. As received DS copper glidcop Al25. SEM micrography.

Figure 5:

Variation of the creep elongation at rupture with the life time.

Creep tests at $450^{\circ} \mathrm{C}$

Figure 6:

Stress dependence of creep strain Creep tests at $450^{\circ} \mathrm{C}$.
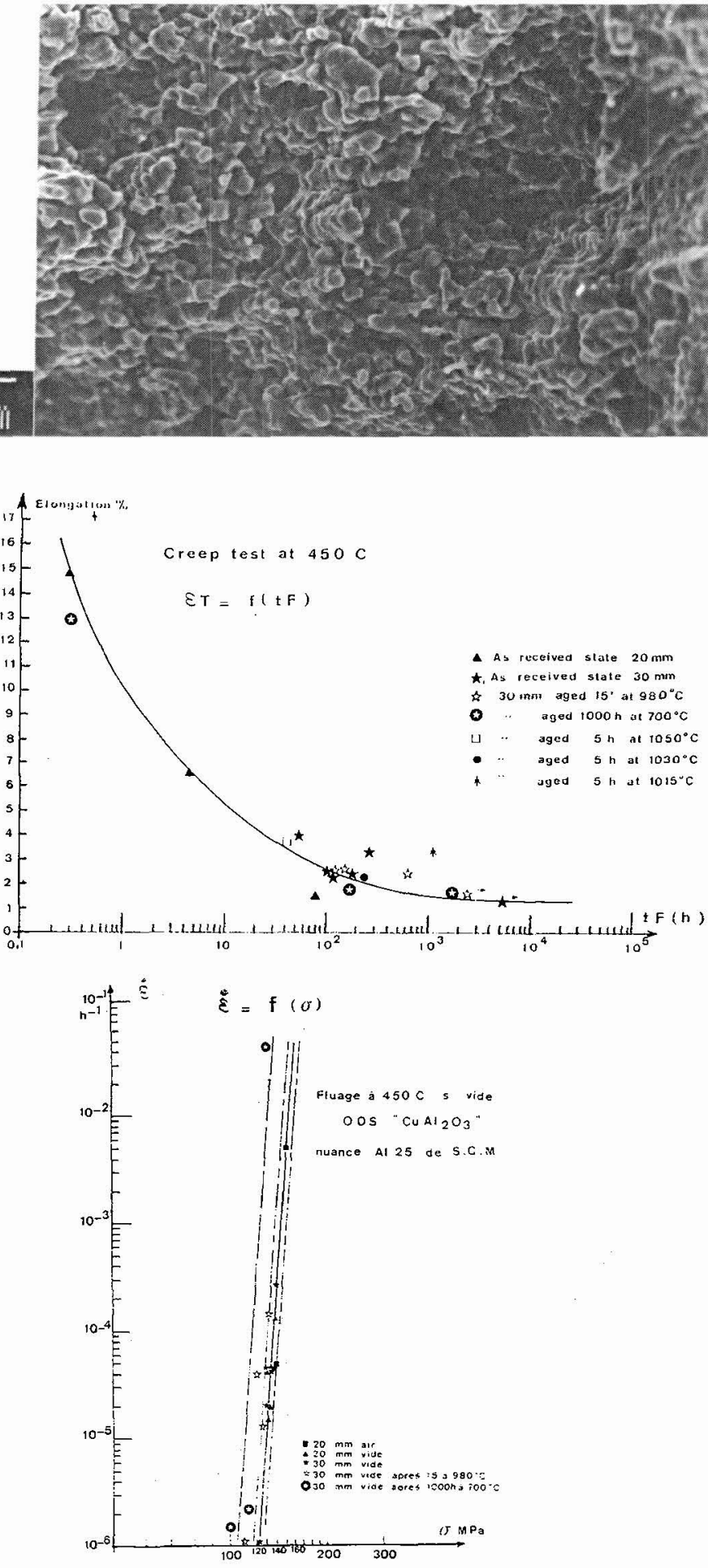